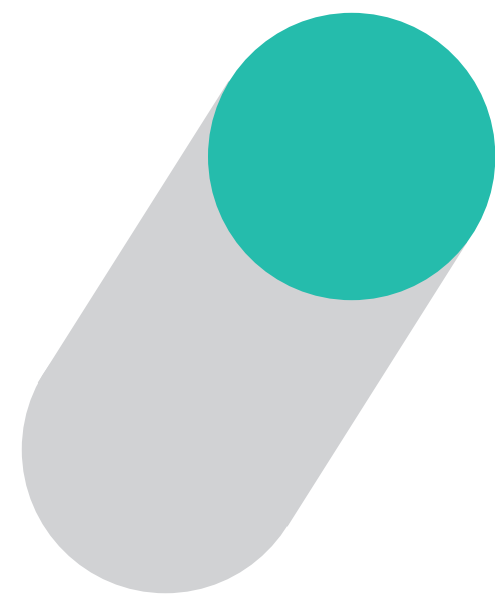

\title{
今日の話題
}

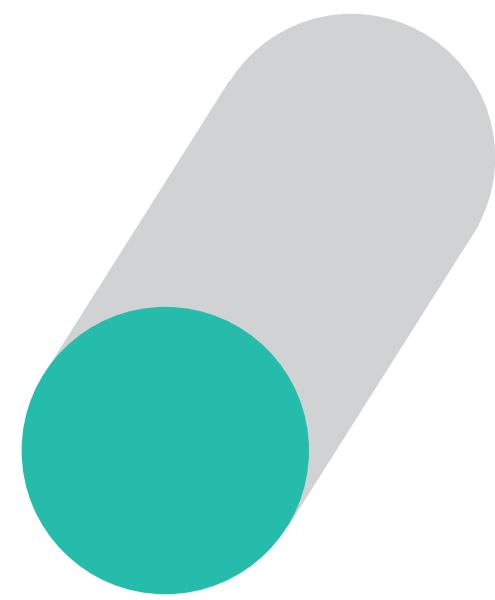

\section{難分解性セサミノール配糖体の分解酵素の発見 期待されるセサミノールの量産化}

ゴマの摂取がヒトの健康に有益な効果をもたらすこと は古くから知られ, 紀元前 3 世紀に中国で著された本草 学の古典にすでにそうした効能の数々が記述されてい る。わが国の科学者はこうしたゴマの健康促進効果の科 学的解明に先駆的な役割を果たし，ゴマ特有の二次代謝 産物ゴマリグナンがその鍵物質であることを明らかにし た ${ }^{(1)}$.ゴマリグナンの一つセサミンの栄養生理機能につ いては特に理解が進み, 健康補助食品の成分として大き な市場が開拓されている。セサミノール（図1）もま た, セサミンにはないユニークな健康促進効果が期待さ れるゴマリグナンの一つである.

肝蔵で部分的な代謝を受けることによって初めて抗酸 化作用を発現するセサミンとは異なり，七サミノールは それ自体で強い抗酸化活性を示す ${ }^{(2)}$. 食用油のなかでゴ マ油が例外的に酸敗しにくいことのおもな理由も，ゴマ 油にセサミノールが含まれることによる ${ }^{(2)}$ 。この強い抗 酸化活性と関連して，セサミノールには変性LDLの生 成抑制作用やDNAの酸化的障害の抑制作用などがある ことも示されている ${ }^{(3,4)}$. こうしたことから，健康食品 素材や化粧品素材としてセサミノールに高い期待が寄せ られてきた。 セサミノールはゴマ種子中では配糖体（セ サミノールトリグルコシド, STG；図1）として存在 し ${ }^{(5)}$, これは生理活性がマスクされた化学形態とみなす ことができる.STGは，ゴマ油の製造の過程で大量に 副成するゴマ搾り粕に含まれるため，ゴマ搾り粕からこ れを抽出してセサミノールに変換することは，安価な天 然資源から高付加価值物質を取得できる有効なアプロー
チであると古くから考えられてきた ${ }^{(6)}$.しかしながら STGは，おそらくその $\beta$ - 1,2 -結合を含む分岐グリコン構 造やかさ高いアグリコン構造のため, 酵素的分解が著し く困難であり，その有効利用が妨げられてきた。最近に なって, 単独でSTGを効率良く分解してセサミノール を生成する酵素 (STG-hydrolyzing $\beta$-glucosidase from Paenibacillus sp.: PSTG) が見いだされ ${ }^{(7)}$ ，バイオアク ターによるSTGからのセサミノールの生産に大きな期 待が寄せられるようになった。

PSTG生産微生物（KB05489株）はゴマ搾り粕から単 離され, Paenibacillus 属細菌の新種であると推定され た.この微生物の細胞抽出液から各種のカラムクロマト グラフィーにより PSTGが均一状態に精製され，全長の 同酵素遺伝子も取得された. PSTG 遺伝子には753アミ ノ酸からなるタンパク質がコードされ，その推定アミノ 酸配列は，同属の微生物が生産するグルコセレブロシ ダーゼ (糖脂質分解酵素) ${ }^{(8)}$ の配列と最も高い類似性 (同一性 63\%) を示した（PSTGはグルコセレブロシ ダーゼ活性を示さない). 系統解析の結果, PSTGはグ リコシドヒドロラーゼ $(\mathrm{GH})$ ファミリー3のメンバーで あることがわかった，GHファミリーとはグリコシダー ゼをアミノ酸配列の類似性に基づいてファミリー単位に 分類したもので，現在 130 以上のファミリーが知られて いる. GH3ファミリーはGHファミリーのなかでも大き な部類に属し，そのグリコン特異性は多様であるが，そ れらの酵素反応はいずれもアノマー炭素立体保持型であ る. 同ファミリーは系統的にさらに少なくとも6つのク 


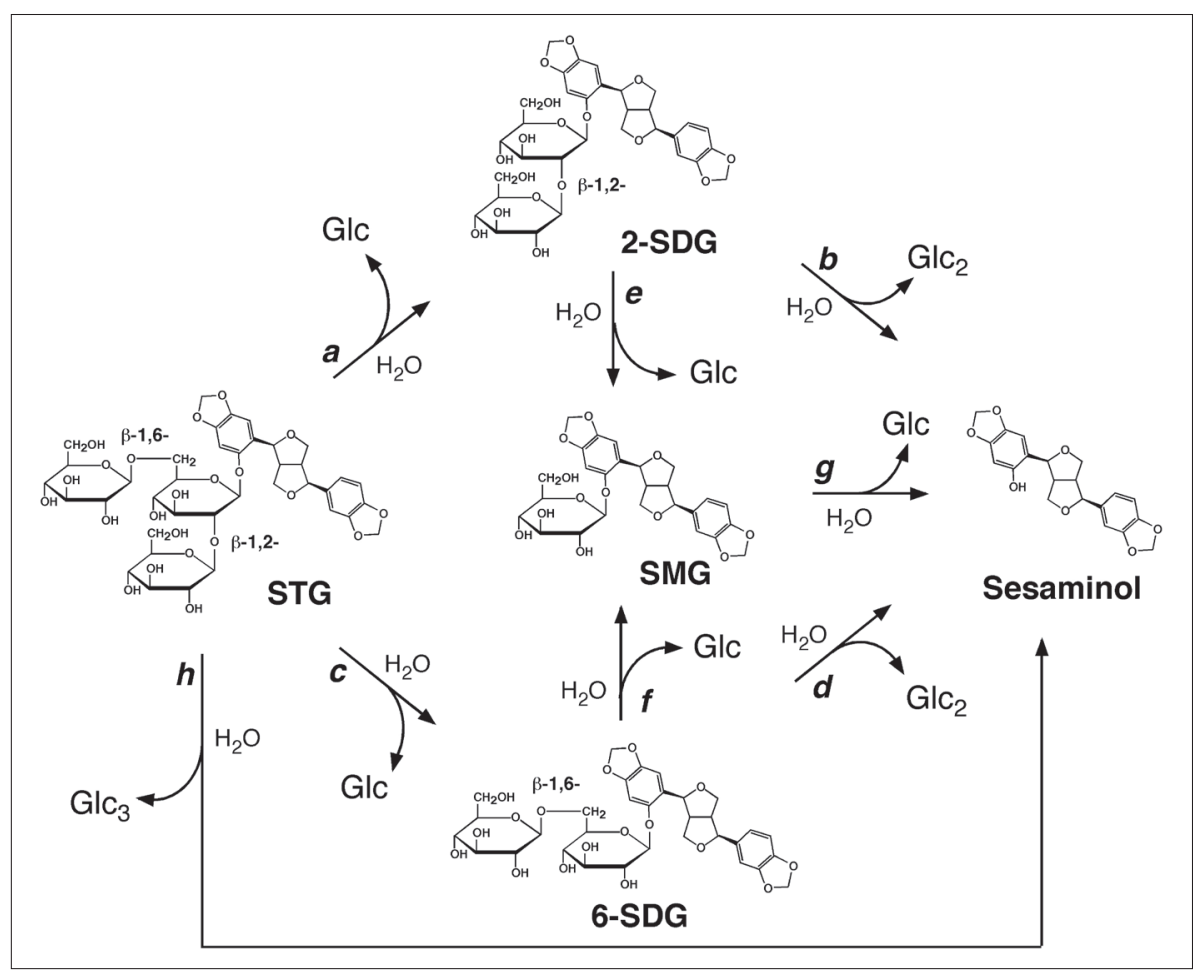

図1・セサミノールおよびセサミ ノール配糖体の構造と, セサミノー ルトリグルコシドの可能な酵素的分 解経路

STG, セサミノールトリグルコシド $(2,6-O-シ ゙(\beta$-D-グルコシル)- $\beta$-D-グルコ シルセサミノール)；2-SDG, 2-O-( $\beta$-Dグルコシル)- $\beta$-D-グルコシルセサミ ノール ; 6-SDG, 6-O- $(\beta$-D-グルコシ ル)- $\beta$-D-グルコシルセサミノール ; $\mathrm{SMG}, \beta$-D-グルコシルセサミノール.
ラスターに仕分けされ(9), PSTGはそのうちのクラス ター5に含まれる。

さて前述のようにPSTGは，単独でSTGからのセサ ミノール生成を効率良く触媒できる初めての酵素であ る. STGの酵素的分解の可能な経路（図1）のなかで, PSTGのこのユニークな STG分解能力がどのルートで 達成されているのかが調べられた. PSTGによるSTG 分解の過程で, 反応系に少量の SMGと比較的多量の 6-SDGが一過的に蓄積すること（セサミノール配糖体の 略号とその構造は図を参照)，ならびにグルコースの 2 量体や 3 量体が生成せず単量体のみが蓄積することが確 認され，本酵素によるSTG分解は，グルコース残基を 一つずつ切り離していく $\beta$-グルコシダーゼ活性に基づ くことがわかった. PSTGはまた, 既往の $\beta$-グルコシ

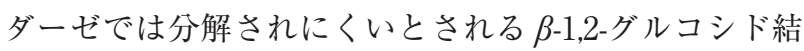

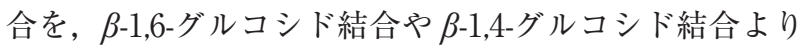
も好んで切断することもわかった. PSTGのSTG分解 活性を $100 \%$ としたとき，2-SDGと6-SDGに対する分解 速度比はそれぞれ $124 \%$ と $53 \%$ であった。 以上の結果を 総合すると, PSTGによるSTG分解は, 図1に示した可 能な反応経路のなかで $\mathrm{c} \rightarrow \mathrm{f} \rightarrow \mathrm{g}$ を主たる経路とし, $\mathrm{a} \rightarrow \mathrm{e} \rightarrow \mathrm{g}$ をマイナーな経路として進行することが示唆 された。

今後, PSTGやPSTG生産微生物を用いたバイオリア クター研究が進展し, セサミノールの量産化が達成され ることが期待される。 また単一の酵素でSTG分子中の すべての $\beta$-グルコシド結合を分解できるというユニー クな特異性が，この酵素の構造のどのような特徴に起因 するのかについて, 今後, 同酵素の立体構造を明らかに したうえで解明していく必要がある.

1）並木満夫編著：“ゴマその科学と機能性”, 丸善出版, 1998.

2) M. Nagata et al. : Agric. Biol. Chem., 51, 1285 (1987).

3) M. H. Kang et al. : Life Sci., 66, 161 (2000).

4) T. Osawa:Mech. Ageing Dev., 111, 133 (1999).

5) H. Katsuzaki et al. : Phytochemistry, 35, 773 (1994).

6）栗山健一, 無類井健夫：農化, 67, 701 (1993).

7) A. Nair et al. : PLoS ONE, 8, e60538 (2013).

8) T. Sumida et al.:J. Biochem., 132, 237 (2002).

9) A. J. Harvey et al. : Proteins: Struct. Func. Genet., 41, 257 (2000).

(中山 亨, 東北大学大学院工学研究科) 
プロフィル

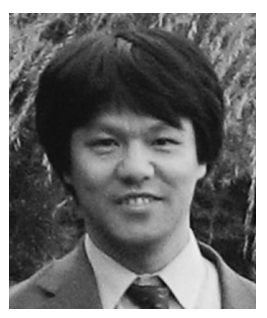

中山 亨 (Toru NAKAYAMA)

<略歴> 1981 年筑波大学第 2 学群農林学

類卒業 / 1983 年京都大学大学院農学研究

科農芸化学専攻修士課程修了 $/ 1986$ 年同

博士課程修了／1986年サントリー株式会

社入社 $/ 1994$ 年神戸学院大学栄養学部助

手 / 1998年東北大学大学院工学研究科生

物工学専攻助教授 $/ 2005$ 年同大学大学院 工学研究科バイオ工学専攻教授, 現在に至 る<研究テーマと抱負 $>$ 植物生化学, 微生 物生化学, 生命現象の酵素科学 <趣味 $>$ ガーデニング, バロック音楽鑑賞 